\title{
STUDENTS IN RESEARCH - EXPERIENCE WITH RESEARCH-BASED TEACHING
}

\author{
Marcin Fojcik $^{1}$, Martyna K. Fojcik ${ }^{2}$, \& Bjarte Pollen ${ }^{1}$ \\ ${ }^{1}$ Department of Electrical Engineering, Western Norwegian University of Applied Sciences (Norway) \\ ${ }^{2}$ Faculty of Humanities and Education, Volda University College (Norway)
}

\begin{abstract}
One of the challenges of today's universities is to adapt the sharing of knowledge to the needs of modern students. Today's students want an education that is relevant, engaging and interesting, and which should provide good job opportunities. Unfortunately, it is not possible to predict what kind of knowledge will be needed in a few years' time. Therefore, universities and colleges must not emphasise specific topics, because they can be soon outdated, but they should rather emphasise innovation, curiosity, arousal of interest, partnership and interdisciplinary cooperation. Different research shows that the activity of students is critical for their learning outcome. Therefore, engaging students in present research can be a way of helping them to learn.

On Western Norway University of Applied Sciences (HVL) and Volda University College (HVO) we are working to improve the quality of teaching through research-based teaching. This means that teachers can integrate research with their own teaching and involve students in it. It is about facilitating students to contribute to innovation and research, as well as showing that their ideas can be interesting and important. Usually, students do not understand the whole research process, but can participate in some parts of it. This participation can be very helpful in carrying out smaller tasks, like collecting, analysing and processing the data.

There are many factors which can both help or prevent the process of learning. These include such elements as: teaching style, form of learning and resources. Modern teachings styles, like for example streaming, can give the students better flexibility of learning, but in the same time it can increase the distance between teachers and students. The style of teaching is also important. There are different methods of teaching; lectures, exercises, labs and projects, and all of them have different effect on students learning process.

We at the HVL and HVO have practice similar activities. We have had many projects with students participating in research with good results. In addition, our students presented their results at national and international conferences. We want to share our experience and present our projects, research and experience in close cooperation with students and discuss how this has affected their motivation to learn and develop their competences.
\end{abstract}

Keywords: Active learning, integrated learning, students as researchers.

\section{Introduction}

Education is important for getting prepared for both everyday life and working carrier. Society, governments, researchers, teachers, parents and students are interested in effective learning and skill development. But how can universities perform good and practical education? What methods fits best for the requirements from teachers, governments and societal needs, and the expectation of students? Everyone wants to be motivated for learning and development, but not everyone prefers the same learning strategies or educational approach.

Practical education can give necessary knowledge and skills, by creating opportunities for the students to explore and gather experience in different situations. There are many new teaching concepts and approaches as Project-Based Learning, Active Learning, Inquiry-Based Learning and many more (Fojcik, Fojcik, Pollen, Helgesen \& Mjånes, 2020). These concepts set student as a central person in the learning process and supports students' journey for gathering practical and applied knowledge. It means that all activities are design to approximate concepts and methods the students need for further workplace. Such approaches are usually in close collaboration with the industry or companies that desires to get well educated workers. 
The other possibility, or more precise extension of previous concepts is research-based learning (RBL). This concept aspires to motivate student for exploring new concepts, models, connections and relations. The idea is to involve the students in research process, to help them understand and learn not just the practical skills for everyday life, but also the possibilities for changing the world. Universities today have at least to types of activities: education and research. Traditionally education is for the students and the research for teachers. But there is an opportunity to invite students to research. (Lillejord, Børte, Nesje \& Ruud, 2018). There are mange advantages and disadvantages of this idea, that the authors would like to analyse in this study based on experience in teaching RBL, mentoring and assessing students research projects and inviting students to participate in national and international research.

\section{Background}

One big advantage of RBL is to give the students to participate in discovering and exploring activities, as well as documenting and proving theories (National Academies of Sciences, Engineering, and Medicine, 2015). Students can be motivated by analysing relations between concepts that no one have done before. In today's world, there are not many more islands to find or species to discover, but there are many research fields that are still under explored. Inviting students to the research can give another perspective and new ideas to explore.

Students as researchers" is a kind of pedagogy focused on the research process. The research can involve the use of teaching and learning methods and the use of practical tasks that relate to research (Anderson and Priest, 2014); teachers should place emphasis on practical and creative thinking skills so that students can carry out their ideas, assess the quality of their arguments or methods, and work as a group on projects.

Students in research should not be treated as subject or elements, but as young scientist that have much potential for development and are eager to learn. The students are not only supposed to acquire own knowledge, but they should participate in something completely new and unknown. It is a common misconception that humanity today now everything, and when somebody is curious about something it is enough to "google it". Showing students that knowledge is something that needs to be explored, analysed and proved can be beneficial for extending their understanding. Students engage in research, using knowledge gained in or outside the classroom, and then prepare the research process. Involvement in research-based education can encourage students to further develop and critically appraise their experiences (Kincheloe and Steinberg, 1998).

PBL is a teaching approach for letting students acquire skills that cannot, or are difficult to acquire in other way. This method is probably more difficult, since the students are uncertain ground, where no one have been before. That makes it challenging for the supporting teacher/researcher to organize, prepare and guide students towards concrete goals, when the results are not given. In RBL the teacher/researcher should explain the methods which will be used in this project and engage the students in the process by assigning them to a suitable type of research activities. Students, without suitable knowledge, skills and experience, should not do all research work immediately and individually. The process has to be tailored to the student's skills and capabilities (Wulf-Andersen, Mogensen \& Hjort-Madsen, 2013).

On the other hand, Cook- Sather (2014) suggests that research partnerships are old-fashioned concepts because they change the way we act and think, and engage in situations that may appear to conflict with common ways of doing things. In this perspective the knowledge the students acquire during research-based learning may not be directly equivalent with practical experience gathered by doing projects and learning already established and proved concepts.

\section{Description}

To involve students in doing research is not an easy task. It should be prepared in detail and according to a plan. A part of the challenge is the expectation. When $\mathrm{PhD}$ student is participating in research it is quite normal and even expected, but master or bachelor students have not much experience yet. That does not mean that they should not do research, it only states facts that those students should be guided and supervised through the process, which can be a challenge for the teachers. Master and bachelor students can gain experience through researching and developing skills needed in research. There are some universities which have their research program for students (Andersen, Olesen, Weber, Dybbroe, Andersen, Kampmann, Warring \& Meldstad, 2005). Many examples of "students as researchers" can be found in Healey and Jenkins (2009) and Healey, Lannin, Stibbe and Derounian (2013). 
There are many international conferences with special session only for student's research, and there are programs within European Union for young researchers. Those kinds of activities have a goal to promote research to younger generations and provide them with necessary resources for exploring and discovering existing research fields and developing new ones.

On Western Norway University of Applied Sciences (HVL) there are some subject in which the students have the opportunity to join research project or to prepare their own. The students are invited to share experience through participation in conferences, meetings, workshops, international research. Some students use the knowledge acquired with implementation or application of research in job-interviews, while others participate in national or international conferences, sometimes even with presenting own projects and publishing papers in Springer. From 1999/2000 till now project-based learning has been part of the learning in the bachelor's degree in automatization engineering. The goal of doing a project each semester is that the assignment or problem should be relevant to the content the students learn about, so that working both with the theory in the subject and in practical application of the project can support student learning and helping them to gain relevant experience.

There are different types of projects, from practical (as preparation of the whole parking system control system - hardware, software, installation and commissioning) to theoretical (as preparation of methods and calculations for battery ferry power plants - with dimensioning of power lines, batteries, schedules, transport possibilities, efficiency calculations and economic return). Sometimes project assessment is not easy due to different content and methods used. This requires the cooperation of many teachers from different subjects. This is time and resource consuming.

As result of projects and inspired with working with RBL some students on HVL participated on sustainable workshops - they present bachelor project amount environmentally friendly using prototype of automated woodworking machine. Some students planned, designed and made prototype of machine for studding of tires for lorries. Other participated in international research about modern communication systems - and limitations in industry data transmission. The results were presented on international conference and published.

In Volda University College (HVO) the research-based learning is used in some parts of teacher education. In some courses for postgraduate courses the students are creating own individual projects in combining programming with didactics research. The students are engaging with own pupils (in primary school) for creating robots. Such student needs to allow own pupils to participate in their projects, support pupils thinking and helping them to develop a final product. A unique robot that they made themselves. At the end of the semester every student need to collect data form own pupils and analyse the data according to own knowledge and experience both in programming and didactics. The data needs to be documented and reflected on in a final rapport that will give be assessed with the final grade of the course.

\section{Discussion}

Cook- Sather (2014) uses employee reflections to show that while a partnership between students and employees can be troublesome, both groups can benefit from the cooperation. This applies to both students and staff when they engage in partnerships. Such partnership is not even is the sense that both parties can do the same amount of work, or the work at the same level, but both parties can be beneficial with ideas, creativity and critical thinking. Sometimes there are different perspectives on a problem or a solution that can be discussed and compared. Students involved in research-based education can also transfer these critical thoughts from academic life to everyday life, as discussed in Sharp et al. (20xx).

As Fielding says: "Transformation requires a break with the ordinary, and this requires as much from teachers as from students. Indeed, it requires transformation of what it means to be a student; what it means to be a teacher" (2004, pp. 296). Apart from the often-troublesome aspects of this undertaking, employees and students still must cope with institutional constraints, social problems and lack of resources at the university. This may make a drastic change in pedagogy very difficult in practice and difficult without the support of the institution in which the changes are made. To achieve this, teachers and administration should create time and space in the curriculum, giving students time to work with others on projects, and create assessments that do not require students to remember facts and ideas (Martin \& Hodge, 2011).

Research is often expensive (time, money, equipment) - without any guaranty to get back resources. Universities can use own funds - what is not popular - or research funds for example from European Union projects or national funds. The challenge in these situations is that there is a large competition for most of those projects, and participation of undergraduate students does not help to obtain resources since they need to be guided and supervised.

Implementing RBL in study programs in higher education institutions can help the students to organise time and place for research projects. There are institutions that introduces research in courses, in a way that can combine standard curriculum with research projects. The concepts "students as researchers" 
is based on experience with such courses and programs (Elmesky \& Tobin, 2005). Students as researchers can ask about the curriculum, or more broadly about education: "What is worth knowing here? How do we know this? What benefit do we derive from this knowledge?" (Kincheloe and Steinberg, 1998b, pp. 238). Therefore, planning, structuring research into working plan and communication with students through the project are crucial for their understanding and confidence. Combining RBL with lectures about topics the student research can motivate students for further learning (Andersen et al, 2005)

Another element that should be considered before combining RBL in courses and making students as researchers, is the ethical problems. How to rate student's participation in research? Should they be authors, co-authors of presentation, publication? How big was their impact to project results? All those arguments should be answered before starting the implementation of RBL as part of a course. It happens that students are mentioned as co-authors of articles in trade journals, but they are usually credited for their thanksgiving work. It is rare for students to be fully involved in both writing and reviewing. The full involvement and benefits of the research will not be realised until the reviews and publications are standard expectations of these critical experiences.

\section{Conclusions}

There are advantages and disadvantages of the RBL. The good elements are practical experience, possibility to participate in big, real research group, with communication, collaboration and common responsibility. The gained skills are, according to students' feedback, relevant to job and useful in practice. In addition, cooperation with specialist can increase motivation both to actual and further plan for work, also to teaching. This was observed in discussion with the students on HVL after finalizing the research project. The students want to learn more and ask about further projects.

One of the disadvantages is that not all of the students are interested in research - for many reasons, like not enough time, lack of interest or not enough skills. Another challenge is the plan for the course. To put research into standard course, with detailed curriculum, is very challenging. One problem is the possibility to assess students input and knowledge and grading them. In research it is not so easy to use standard forms of learning outcome, since there are many variables that can affect the results. Therefore, it is necessary to have experienced and active teachers. Teachers without experience cannot motivate and guide the students of "engage to research". The challenge is that typical teachers have not enough skills, while experienced professors have not enough time to work with students.

During many years of teaching and involving students the authors can see some patterns. Most of the students are unsure of new activities. This is an emotion that can prevent them from trying their skills in the research field. Those students need some years of experience and engagement to get involved. It is much easier to achieve if previous students can invite the younger ones.

Research-based learning can be very interesting form of teaching. It can give students competences in collaboration, understanding real problems and solving practical tasks. This method is not for all students and not for all teachers. Participation is not question about personal parameters but independent factors like lack of resources and personal motivation for discovery.

\section{References}

Andersen, L. L., Olesen, H. S., Weber, K., Dybbroe, B., Andersen, A. S., Kampmann, J., Warring, N., \& Meldstad, M. (2005). Training Young Researchers in Lifelong Learning: Self-evaluation report from the GraduateSchool in Lifelong Learning. Roskilde Universitet.

Anderson and Priest, 2014 - Anderson, J., \& Priest, C. (2014). Developing an inclusive definition, typological analysis and online resource for Live Projects. In Architecture Live Projects (pp. 9-17). Routledge.

Cook-Sather, A. (2014). Student-faculty partnership in explorations of pedagogical practice: A threshold concept in academic development. International Journal for Academic Development, 19(3), 186-198.

Elmesky, R., \& Tobin, K. (2005). Expanding our understandings of urban science education by expanding the roles of students as researchers. Journal of Research in Science Teaching, 42(7), 807-828.

Fielding, M. (2004). Transformative approaches to student voice: Theoretical underpinnings, recalcitrant realities. British educational research journal, 30(2), 295-311.

Fojcik, M., Fojcik, Martyna M. K., Pollen, B., Helgesen, C., Mjånes, J. O. R., (2020), Structuring educational concepts for applied STEM teaching, EDULEARN2020, IATED Digital Library - in review 
Healey, M., \& Jenkins, A. (2009). Developing undergraduate research and inquiry (p. 152). York: Higher Education Academy.

Healey, M., Lannin, L., Stibbe, A., \& Derounian, J. (2013). Developing and enhancing undergraduate final-year projects and dissertations. York: Higher Education Academy.

Kincheloe, J. L., \& Steinberg, S. R. (1998). Making meaning and analyzing experience-student researchers as transformative agents. Students as researchers: Creating classrooms that matter, 228-247.

Lillejord S., Børte K., Nesje K. \& Ruud E. (2018). Learning and teaching with technology in higher education - a systematic review. Oslo: Knowledge Centre for Education

Martin, C. T., \& Hodge, M. (2011). A nursing department faculty-mentored research project. Nurse Educator, 36(1), 35-39.

National Academies of Sciences, Engineering, and Medicine. (2015). Integrating discovery-based research into the undergraduate curriculum: Report of a convocation. National Academies Press.

Sharp, J. (2012). Success with your education research project. Learning Matters.

Wulf-Andersen, T., Mogensen, K. H., \& Hjort-Madsen, P. (2013). Researching with Undergraduate Students: Exploring the Learning Potentials of Undergraduate Students and Researchers Collaborating in Knowledge Production. Journal of Research Practice, 9(2), M9. 